\title{
Development of Cooperative Research Project Based Learning Models to Improve Research and Communication Skills for Prospective Physics Teachers in Indonesia
}

\author{
Fitri April Yanti, Heru Kuswanto, Mundilarto, Habibi
}

\begin{abstract}
Achievement of learning objectives is supported by the use of appropriate learning models. The research skills and communication of prospective physics teachers is an important ability that is mastered by prospective physics teachers. A learning model is needed that can improve the research and communication skills of prospective physics teachers. This study aims to (1) produce a prototype of the CORPjBL model to improve the research and communication skills of prospective physics teachers, (2) Produce appropriate CORPjBL models to improve the research and communication skills of prospective physics teacher and (3) produce CORPjBL models that can effectively improve skills research and communication of prospective physics teacher. This research is a research and development using the ADDIE step. The ADDIE step consists of analysis, design, develop, implementation and evaluation. The trial subjects included the candidates for the fifth semester physics education teacher who took the physics learning strategy course 2018/2019 school year. The sample used was 3 classes. Data need assessment was collected by questionnaire, interview, and observation. The feasibility data of the learning model was collected by questionnaire sheet, interview sheet, and validation sheet. Data were analyzed descriptively, and infrerential statistics using MANOVA. The research findings are (1) The prototype CORPJBL model produced has a preliminary section, a theoretical basis and the contents of the model consisting of syntax, social systems, reaction principles, support systems, and learning and accompaniment impacts. The CORPjBL model syntax is group formation and problem finding, research project planning, research project implementation, analysis of research project data, assessment and dissemination of research results. (2) The CORPJBL model is appropriate to use according to expert and practitioner ratings. The quality of the feasibility of the model is in very good criteria. (3) The CORPjBL model is effectively used to improve research and communication skills of prospective physics teacher.
\end{abstract}

Keywords: Cooperative research project based learning model, research skills, communication skills, prospective physics teacher, learning model.

\section{INTRODUCTION}

Teachers play an important role in developing the quality of students. The quality of the process and learning outcomes lies in their role in carrying out their duties professionally. Teachers in their professional development are required to be able to conduct scientific publications. But in fact, teachers are still experiencing difficulties in

\footnotetext{
Revised Manuscript Received on April 19, 2019.

Fitri April Yanti,

Heru Kuswanto

Mundilarto

Habibi.
}

conducting scientific publications (Lestari \& Susanto, 2010; Trisdiono, 2016). Teacher's scientific publications decline every year. In 2009 the results of teacher scientific publications reached $86 \%$ and in 2012 it decreased to $14 \%$ (Udompong et al, 2014). The decline in teacher scientific publications is due to limited knowledge and skills in research (Chalardyam, 2001; Goodnough, 2001; Gilbert \& Smith, 2003). Teach research skills are obtained when they become teacher candidates. In addition to research skills, communication skills are important skills for prospective physics teachers. However, the communication skills of prospective physics teachers received less attention in many universities in Indonesia. Based on the results of the semester learning plan analysis, communication skills were not a priority of the learning outcomes of prospective physics teachers. This resulted in them graduating with mastery of knowledge, but they did not know how to convey that knowledge (Awang \& Daud, 2015).

The subject of physics learning strategy is one of the subjects that allows to be taught research skills and communication skills for prospective physics teachers. The characteristics of this course examine and analyze the nature of learning strategies, various types of learning strategies, and to intensify learning cases to achieve optimal learning outcomes. However, the lecture process that has taken place is more spent in the classroom. This is because lecture activities are dominated by the presentation of each meeting and observation at the end of the meeting. Field observation activities were conducted once a meeting with problem solving was considered to be finished in class, so there was no follow-up on the problems found.

The importance of research skills and communication skills for prospective physics teachers requires a learning model to improve both. Research skills are needed by prospective physics teachers to solve physics learning problems. Communication skills are needed by prospective physics teachers in delivering subject matter to prospective students. Increasing both can be realized through the right learning model. Model cooperative research project based learning is a learning model that integrates research projects in learning cooperatively. This model is expected to improve the research skills and communication skills of prospective physics teachers. The model of the cooperative research 
project based learning for prospective physics teachers is developed by taking into account teacher competencies.

\section{METHOD}

This research was conducted to produce a model of the cooperative research project based learning that is feasible and effective. The research design uses the Research and Development (R \& D) method with the ADDIE procedure which consists of 5 stages, namely: (1) Analysis; (2) Design; (3) Develop; (4) Implementation, and (5) Evaluation. The research subjects were physics teacher candidates by random sampling, three experimental classes were obtained. Experiment class 1, experimental class 2 and experimental class 3 each number 30 prospective physics teachers.

Data was collected using observation sheets of communication skills, research skills tests and observation sheets for validation of models and devices. Based on the type of data, the data are analyzed qualitatively and quantitatively. Data validation of learning models and devices (semester learning plans, prospective physics teacher worksheets, and teaching materials) was analyzed descriptively. The effectiveness of the learning model obtained from the implementation of the model for learning is analyzed using MANOVA.

\section{RESULTS}

If you are using Word, use either the Microsoft Equation Editor or the MathType add-on (http://www.mathtype.com) for equations in your paper (Insert | Object | Create New | Microsoft Equation or MathType Equation). "Float over text" should not be selected.

\section{IV.UNITS}

A. Cooperative research project based learning to improve research and communication skill
Based on the results of the preliminary survey and the analysis of the research and communication skills of prospective physics teachers who are still not maximal, a model of the cooperative research project based learning is needed to improve the research and communication skills of prospective physics teachers. Prospective physics teacher research skills include: finding problems, reviewing literature, designing research, conducting research, analyzing data, making conclusions, writing scientific articles, and evaluating research results. Prospective physics teacher communication skills include 4 aspects: Listening, reading, speaking, writing. This means that to improve both, the development of a cooperative research project based learning model needs to integrate these skills. There are five stages of the cooperative research project based learning model, namely: (1) Forming groups and finding problems; (2) Planning Research Projects; (3) Implementation of Research Projects; (4) Research Project Data Analysis; (5) Assessment of Research Results and Dissemination.

\section{HELPFUL HINTS}

\section{A. $\quad$ Figures and Tables}

Because the final formatting of your paper is limited in scale, you need to position figures and tables at the top and bottom of each column. Large figures and tables may span both columns. Place figure captions below the figures; place table titles above the tables. If your figure has two parts, include the labels "(a)" and "(b)" as part of the artwork. Please verify that the figures and tables you mention in the text actually exist. Do not put borders around the outside of your figures. Use the abbreviation "Fig." even at the beginning of a sentence. Do not abbreviate "Table." Tables are numbered with Roman numerals. Include a note with your final paper indicating that you request color printing.

Table 1. The Cooperative Research Model Development Matrix of Project Based Learning in Research and Communication Skills

\begin{tabular}{|c|c|c|c|}
\hline \multirow{2}{*}{$\begin{array}{l}\text { Indicator } \\
\text { Research Skill }\end{array}$} & \multirow[b]{2}{*}{ Lecturer Activity } & \multirow{2}{*}{$\begin{array}{l}\text { Activity of Prospective } \\
\text { physics teachers }\end{array}$} & \multirow{2}{*}{$\begin{array}{l}\text { Indicator } \\
\text { Communication } \\
\text { Skill }\end{array}$} \\
\hline & & & \\
\hline \multicolumn{4}{|c|}{ Phase 1: Form groups and find problems } \\
\hline $\begin{array}{l}\text { Find / } \\
\text { problems }\end{array}$ & 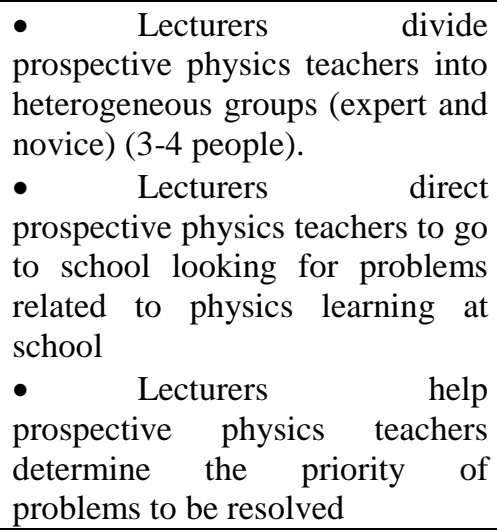 & 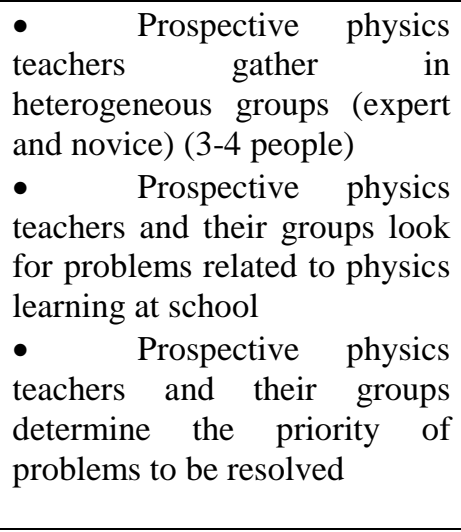 & $\begin{array}{l}\text { Listening, reading, } \\
\text { speaking, writing }\end{array}$ \\
\hline
\end{tabular}




\begin{tabular}{|c|c|c|c|}
\hline \multicolumn{4}{|c|}{ Phase 2: Planning a Research Project } \\
\hline $\begin{array}{l}\text { Review / check the } \\
\text { literature to find a } \\
\text { solution }\end{array}$ & $\begin{array}{l}\text { - Lecturers } \\
\text { prospective physics teachers } \\
\text { determine temporary solutions to } \\
\text { solve problems through literature } \\
\text { review } \\
\text { - The lecturer asks each } \\
\text { group in turn to convey the } \\
\text { temporary solutions they have } \\
\text { obtained. In this section the } \\
\text { lecturer provides a deepening of } \\
\text { the subject matter. } \\
\text { - Lecturers } \\
\text { prospective physics teachers in } \\
\text { literature review activities } \\
\text { through relevant scientific } \\
\text { journals from various sources. }\end{array}$ & $\begin{array}{l}\text { - Prospective physics } \\
\text { teachers determine temporary } \\
\text { solutions to solve problems } \\
\text { through literature review } \\
\text { - Prospective physics } \\
\text { teachers in groups take turns to } \\
\text { convey the temporary solutions } \\
\text { they have obtained. In this } \\
\text { section, analysis of learning } \\
\text { material is carried out. } \\
\text { - Prospective physics } \\
\text { teachers and their groups } \\
\text { conduct literature studies } \\
\text { through relevant scientific } \\
\text { journals from various sources. }\end{array}$ & $\begin{array}{l}\text { Listening, reading, } \\
\text { speaking, writing }\end{array}$ \\
\hline Designing research & $\begin{array}{l}\text { - Lecturers guide students } \\
\text { to make / prepare research } \\
\text { instruments }\end{array}$ & $\begin{array}{l}\text { - Make / prepare } \\
\text { research instruments }\end{array}$ & $\begin{array}{l}\text { Listening, reading, } \\
\text { speaking, writing }\end{array}$ \\
\hline \multicolumn{4}{|c|}{ Phase 3: Implementation of Research Projects } \\
\hline Carry out research & $\begin{array}{l}\text { - Lecturers make sure } \\
\text { prospective physics teachers are } \\
\text { ready to carry out research } \\
\text { - Lecturers } \\
\text { prospective physics teachers so } \\
\text { that they cooperatively conduct } \\
\text { research with practitioners } \\
\text { - Lecturers prepare } \\
\text { research letters for prospective } \\
\text { physics teachers } \\
\text { - Lecturers assess progress } \\
\text { reports given by prospective } \\
\text { physics teachers }\end{array}$ & $\begin{array}{l}\text { - Prospective physics } \\
\text { teachers carry out research by } \\
\text { applying new concepts to solve } \\
\text { problems at school. } \\
\text { - Prospective physics } \\
\text { teachers carry out cooperative } \\
\text { research with education } \\
\text { practitioners } \\
\text { - Prospective physics } \\
\text { teachers collect research data } \\
\text { - Prospective physics } \\
\text { teachers report the } \\
\text { development of research }\end{array}$ & $\begin{array}{l}\text { Listening, reading, } \\
\text { speaking, writing }\end{array}$ \\
\hline \multicolumn{4}{|c|}{ Phase 4: Data Analysis of Research Projects } \\
\hline Analyze data & $\begin{array}{l}\text { - Lecturers } \\
\text { prospective physics teachers in } \\
\text { analyzing and confirming the } \\
\text { results of data collection }\end{array}$ & $\begin{array}{l}\text { Prospective physics } \\
\text { teachers carry out analysis and } \\
\text { confirm the results of data } \\
\text { collection }\end{array}$ & \multirow[b]{2}{*}{$\begin{array}{l}\text { Listening, reading, } \\
\text { speaking, writing }\end{array}$} \\
\hline Make conclusions & $\begin{array}{l}\text { - Lecturers guide } \\
\text { prospective physics teachers to } \\
\text { conclude research projects }\end{array}$ & $\begin{array}{l}\text { - Prospective physics } \\
\text { teachers make and submit } \\
\text { conclusions of research } \\
\text { projects based on the results of } \\
\text { data analysis. }\end{array}$ & \\
\hline \multicolumn{4}{|c|}{ Phase 5: Assessment and Dissemination of Research Results } \\
\hline $\begin{array}{l}\text { Writing } \\
\text { articles }\end{array}$ & $\begin{array}{l}\text { Lecturers guide prospective } \\
\text { physics teachers to write } \\
\text { scientific articles }\end{array}$ & $\begin{array}{l}\text { Prospective physics teachers } \\
\text { and their groups write } \\
\text { scientific articles }\end{array}$ & $\begin{array}{l}\text { Listening, reading, } \\
\text { speaking, writing }\end{array}$ \\
\hline
\end{tabular}


International Conference on Recents Advancements in Engineering and Technology (ICRAET-18) |15th and 16th March 2019|Siddhartha Institute of Technology \& Sciences, Telangana, India.

\begin{tabular}{|c|c|c|c|}
\hline $\begin{array}{l}\text { Evaluating research } \\
\text { results }\end{array}$ & $\begin{array}{l}\text { - Lecturers assess the } \\
\text { prospective physics teacher's } \\
\text { scientific articles } \\
\text { - Lecturers } \\
\text { prospective physics teachers } \\
\text { publish articles in campus } \\
\text { journals } \\
\text { - Lecturers conduct an } \\
\text { assessment of the teacher's } \\
\text { research and communication } \\
\text { skills tests } \\
\text { - Lecturers } \\
\text { prospective physics teachers } \\
\text { evaluate research errors }\end{array}$ & $\begin{array}{l}\text { - Prospective physics } \\
\text { teachers and their groups } \\
\text { present scientific articles. } \\
\text { - Prospective physics } \\
\text { teachers publish their articles } \\
\text { in campus journals } \\
\text { - Prospective physics } \\
\text { teachers work on research } \\
\text { skills tests } \\
\text { - Prospective physics } \\
\text { teachers and lecturers evaluate } \\
\text { research errors } \\
\text { - Prospective physics } \\
\text { teachers receive awards for the } \\
\text { best research group } \\
\text { achievements }\end{array}$ & $\begin{array}{l}\text { Listening, reading, } \\
\text { speaking, writing }\end{array}$ \\
\hline
\end{tabular}
learning model was carried out by three expert judgments and three practitioners. The aspects assessed by expert

Table 2. Results of Learning Device Validation

\begin{tabular}{|c|c|c|c|c|}
\hline No & Device / instrument & Respondents & Average & Criteria \\
\hline \multirow[t]{6}{*}{1} & \multirow[t]{6}{*}{ Model Guide } & Expert 1 & 3,9 & Very good \\
\hline & & Expert 2 & 3,8 & Very good \\
\hline & & Expert 3 & 3,8 & Very good \\
\hline & & lecturer 1 & 3,8 & Very good \\
\hline & & lecturer 2 & 3,8 & Very good \\
\hline & & lecturer 3 & 3,7 & Very good \\
\hline \multirow[t]{6}{*}{2} & \multirow[t]{6}{*}{ RPS } & Expert 1 & 3,9 & Very good \\
\hline & & Expert 2 & 4,0 & Very good \\
\hline & & Expert 3 & 4,0 & Very good \\
\hline & & lecturer 1 & 4,0 & Very good \\
\hline & & lecturer 2 & 3,7 & Very good \\
\hline & & lecturer 3 & 3,9 & Very good \\
\hline \multirow[t]{6}{*}{3} & \multirow[t]{6}{*}{ LKCG } & Expert 1 & 3,5 & Very good \\
\hline & & Expert 2 & 3,6 & Very good \\
\hline & & Expert 3 & 3,8 & Very good \\
\hline & & lecturer 1 & 3,2 & Very good \\
\hline & & lecturer 2 & 3,8 & Very good \\
\hline & & lecturer 3 & 4,0 & Very good \\
\hline \multirow[t]{6}{*}{4} & \multirow[t]{6}{*}{ Teaching Material } & Expert 1 & 3,8 & Very good \\
\hline & & Expert 2 & 3,8 & Very good \\
\hline & & Expert 3 & 3,8 & Very good \\
\hline & & lecturer 1 & 3,7 & Very good \\
\hline & & lecturer 2 & 3,8 & Very good \\
\hline & & lecturer 3 & 3,8 & Very good \\
\hline
\end{tabular}

The results of the analysis of the influence between

The results of the validation of the learning model and the device are in very good criteria. It can be concluded that the learning model and the device show valid results.

\section{Effectiveness of Learning Models}

The effectiveness of the cooperative research project based learning model to improve the research and communication skills of prospective physics teachers. Assessment of teacher knowledge is done by giving a quiz at the end of the meeting. Knowledge assessment focuses on aspects of the research skills of prospective physics teachers using test multiple choice. 


\begin{tabular}{|c|c|c|c|c|}
\hline $\begin{array}{c}\text { Dependent } \\
\text { variable }\end{array}$ & Model & Mean & $\mathbf{F}$ & Sig. \\
\hline \multirow{4}{*}{$\begin{array}{l}\text { Researc } \\
\text { h Skill }\end{array}$} & CORPjBL & 14,33 & 10,67 & \\
\hline & Model & 3 & &, 00 \\
\hline & $\begin{array}{l}\text { Conventiona } \\
1 \text { Model }\end{array}$ & 5,500 & & \\
\hline & $\begin{array}{l}\text { Discussion } \\
\text { Model }\end{array}$ & 7,167 & & \\
\hline \multirow[t]{3}{*}{$\begin{array}{l}\text { Commu } \\
\text { nication Skill }\end{array}$} & $\begin{array}{l}\text { CORPjBL } \\
\text { Model }\end{array}$ & $\begin{array}{r}84,76 \\
4\end{array}$ & $\begin{array}{l}126,5 \\
51\end{array}$ &, 00 \\
\hline & $\begin{array}{l}\text { Conventiona } \\
1 \text { Model }\end{array}$ & $\begin{array}{r}72,46 \\
5\end{array}$ & & \\
\hline & $\begin{array}{l}\text { Discussion } \\
\text { Model }\end{array}$ & $\begin{array}{r}73,25 \\
0\end{array}$ & & \\
\hline
\end{tabular}

Table 3 shows that the influence of the learning model on research skills, the $\mathrm{F}$ value is 10.670 and the significance value is $<0.005$, which means that there are differences in the research skills of prospective physics teachers who study with the CORPjBL model, conventional models and discussion models. The effect of the learning model for teaches communication skills, the F value is 126.551 and the significance value is $<0.005$, which means that there are differences in the communication skills of prospective physics teachers who learn with the CORPjBL model, conventional models and discussion models.

The mean values in Table 7 show that the value of research skills in the CORPjBL model group $(M=14,333)$ was higher than the conventional model group $(\mathrm{M}=5,500)$ and discussion model $(\mathrm{M}=7,167)$. The value of communication skills is also the same, the value of communication skills in the CORPjBL model group $(\mathrm{M}=$

$84,764)$ is higher than the conventional model group $(\mathrm{M}=$ $72,465)$ and discussion models $(73,250)$.

\section{DISCUSSIONS}

Research skills are used to find problems related to physics learning that are solved using science. Research skills and communication skills will build prospective physics teachers as a driver of the development of new pedagogical practices (Pandian \& Balraj, 2010). In 21st century skills prospective physics teachers need to master learning about aspects of learning and innovative skills (OECD, 2013: 4).

The essence of research groups is interdependence among its members (created through shared goals) which causes the group to have and become a "dynamic entity". Cooperative research project based learning to improve research skills and communication skills will not be carried out individually. In the research process, prospective physics teachers carry out research activities based on the research methodology that has been determined for their research. Research is conducted to produce solutions and unite their knowledge which will then produce new knowledge in the form of scientific articles.

The strategy for developing research skills is to conduct research in learning in the form of projects. The research project will provide prospective physics teachers an understanding of the research process. While the strategy for developing prospective teaching communication skills is cooperative learning. Cooperative learning will lead teacher brokers to effective communication skills. Awards are given to the CORPjBL group for improving the research skills and communication skills of prospective physics teachers. Research skills can be assessed by tests, while communication skills are assessed by observation.

Implementation of the CORPjBL model begins by validating the product learning model and its supporters. The results of model book validation can be seen from the aspect of content, design and media declared valid. This means that the model book can be used in the learning process. The learning model has learning procedures that are easy to implement (Joyce \& Weil, 1980). While the tools and learning evaluation tools are arranged as a support for implementing the learning. Learning tools developed are semester learning plans, teaching materials and LKGC (teacher candidate worksheets). The evaluation tool developed is an instrument of research skills and instruments for prospective physics teacher communication skills. All devices and instruments are also validated by experts. The results show that the devices and instruments were declared valid.

The results of implementing the CORPjBL model on limited trials and extensive trials show that the CORPjBL model has an effective impact. Based on a limited trial (the results of the $t$ test) that the teacher candidate communication skills score (final) is higher than the teacher candidate's (initial) communication skills, so does the teacher candidate's (final) research skill score higher than the prospective physics teacher's research skills (initial). Based on extensive trials with the MANOVA test, the results showed that the CORPjBL model was better than the Conventional model and discussion in achieving teacher teacher research and communication skills. Prospective physics teacher research skills include finding problems, reviewing literature, planning research, conducting research, analyzing data, making conclusions, communicating research results in the form of scientific articles, and evaluating research results. CORPjBL's effectiveness in learning, especially in the achievement of research skills is evidence that the practice CORPjBL model is used for prospective physics teachers so that prospective physics teachers can implement all aspects of research skills. Related research was also conducted by Hafsah (2015) on the implementation of research based learning in an effort to improve the quality of learning. The results of his research are: To produce quality graduates, study programs should improve the quality of learning, which emphasizes learning models that can add insight and experience.

The CORPjBL model has advantages, including: (1) this model has a strong theoretical foundation and operational learning procedures, (2) this model is developed with the needs of prospective physics teachers and facilitates developing teacher research and communication skills, (3) this model become a liaison between prospective physics 
teachers and education practitioners to cooperate with each other in improving the quality of learning, (4) Validity and reliability of the model that is undoubtedly because it has been tested by experts in their fields, (5) This model is easy to implement so that.

\section{EDITORIAL POLICY}

The submitting author is responsible for obtaining agreement of all coauthors and any consent required from sponsors before submitting a paper. It is the obligation of the authors to cite relevant prior work.

\section{CONCLUSIONS}

Based on the results of the research that has been done, it can be concluded as follows (1) Development of a cooperative research project based learning model to improve the research and communication skills of physics teacher candidates based on a needs analysis. The CORPjBL model trains prospective physics teachers to be able to solve learning problems in the School. This model produces prospective physics teachers to write scientific work after conducting research. The model syntax consists of five steps, namely the group formation stage and problem finding, research project planning, research project implementation, research project data analysis and the stages of assessment and dissemination of research results. A cooperative learning environment between prospective physics teachers and peers or prospective physics teachers with education practitioners will improve the communication skills of prospective physics teachers. (2) The model of the cooperative research project based learning to improve research and communication skills of prospective physics teachers is declared valid by experts. The expert stated that the CORPjBL model was feasible by giving an assessment of the aspects of content, design and media with an assessment of the excellent category. (3) The model of the cooperative research project based learning is declared effective to improve the research and communication skills of prospective physics teachers. The effectiveness of the model is evidenced by the existence of significant differences in the research skills and communication skills of prospective physics teachers between prospective physics teachers who learn to use a model of the cooperative research project based learning and not. Research skills and communication of prospective physics teachers with a cooperative research project based learning model is better than no.

\section{CONCLUSION}

A conclusion section is not required. Although a conclusion may review the main points of the paper, do not replicate the abstract as the conclusion. A conclusion might elaborate on the importance of the work or suggest applications and extensions.

\section{APPENDIX}

It is optional. Appendixes, if needed, appear before the acknowledgment.

\section{ACKNOWLEDGMENT}

Acknowledgments addressed to Research and Technology Ministry of Finance which has provided financial support through BUDI DN program LPDP.

\section{REFERENCES}

1. Botelho, M. G., Lo, E. C. M., Bridges, S., Mcgrath, C., \& Yiu, C. K. Y. (2013). Journal-Based Learning, a new learning experience building on PBL at HKU. European Journal of Dental Education, 17(1), 1-6 https://doi.org/10.1111/j.1600-0579.2012.00771.x.

2. Bower, M. G., Moloney, R., Cavanagh, M., \& Sweller, N. (2013). Assessing Preservice Teachers' Presentation Capabilities: Contrasting the Modes of Communication with the Constructed Impression. Australian Journal of Teacher Education, 38(8). https://doi.org/10.14221/ajte.2013v38n8.1

3. Brew, A., \& Jewell, E. (2012). Enhancing quality learning through experiences of research-based learning: Implications for academic development. International Journal for Academic Development, 17(1), 47-58. https://doi.org/10.1080/1360144X.2011.586461

4. Burke, C. D., \& Stone, D. R. (2015). Approaches A Research-based Learning Processes Teacher Education Curricula. Review of Educational Research, 26(3), 235241.

5. Cavanaugh, C. S., Barbour, M. K., \& Clark, T. (2009). Research and practice in K-12 online learning: A review of open access literature. International Review of Research in Open and Distance Learning, 10(1). https://doi.org/10.19173/irrodl.v10i1.607

6. Chu, S., \& Kong, H. (2008). Grade 4 Students ' Development of Research Skills Through Inquiry-Based Learning Projects. School Libraries Worldwide, 14(1), 10-37.

7. Chung, Y., Yoo, J., Kim, S.-W., Lee, H., \& Zeidler, D. L. (2016). Enhancing Students' Communication Skills in the Science Classroom Through Socioscientific Issues. International Journal of Science and Mathematics Education, 14(1), 1-27. https://doi.org/10.1007/s10763014-9557-6

8. Cunningham, S. J. (1994). Using a computer conferencing system to support writing and research skill development. ACM SIGCSE Bulletin, 26(4), 5-8. https://doi.org/10.1145/190650.190652

9. Awang, H., \& Daud, Z. (2015). Improving a Communication Skill Through the Learning Approach Towards the Environment of Engineering Classroom. Procedia - Social and Behavioral Sciences, 195, 480 486. https://doi.org/10.1016/j.sbspro.2015.06.241

10. Lestari, S., \& Susanto, D. A. (2010). Peningkatan Profesionalisme Guru Melalui Pelaksanaan PTK Bagi Guru-guru Bahasa Inggris SMK Kota Semarang. Universitas PGRI Semarang.

11. LaBeouf, J. (2016). Research-Based Student Learning at the Post-Secondary Level. Bollinger-Rosado Teaching \& Learning Effectiveness Symposium Proceedings. Retrieved from http://commons.erau.edu/bollingerrosado/2011/19th/3

12. Lambert, C. (2009). Pedagogies of participation in higher education: a case for research-based learning. Pedagogy, Culture \& Society, 17(3), 295-309. https://doi.org/10.1080/14681360903194327

13. Lee, M. H., Wu, Y., \& Tsai, C. (2009). Research Trends in Science Education from 2003 to 2007: A content analysis of publications in selected journals. International Journal of Science Education, 
31(15),

$1999-2020$

https://doi.org/10.1080/09500690802314876

14. Lestari, S., \& Susanto, D. A. (2010). Peningkatan Profesionalisme Guru Melalui Pelaksanaan PTK Bagi Guru-guru Bahasa Inggris SMK Kota Semarang. Universitas PGRI Semarang.

15. Pandian, A., \& Balraj, S. (2010). Driving the agenda of learning by design in science literacy in Malaysia. ELearning, $\quad 7(3)$, 301-316. https://doi.org/10.2304/elea.2010.7.3.301

16. Trisdiono, H. (2016). Analisis Kesulitan Guru Dalam Melaksanakan Penelitian Tindakan Kelas. Widyaiswara Madya LPMP.

17. Udompong, L., Traiwichitkhun, D., \& Wongwanich, S. (2014). Causal Model of Research Competency Via Scientific Literacy of Teacher and Student. Procedia Social and Behavioral Sciences, 116(2001), 1581-1586. https://doi.org/10.1016/j.sbspro.2014.01.438

\section{AUTHORS PROFILE}

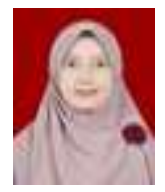

Fitri April Yanti PhD student of Physics Education at Yogyakarta States University.Colombo Street No.1 Yogyakarta, Indonesia. Email: april.ynwa@gmail.com

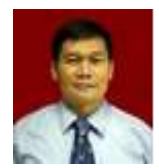

Heru Kuswanto Professor of Physics Education at Yogyakarta States University.Colombo Street No.1 Yogyakarta, Indonesia.Email: herukus61@uny.ac.id

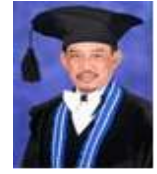

Mundilarto Professor Physics Education at Yogyakarta States University.Colombo Street No.1 Yogyakarta, Indonesia. Email: mundilarto@uny.ac.id

Habibi HabibiPhD student of Physics Education at

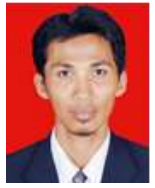
Yogyakarta States University.Colombo Street No.1 Yogyakarta, Indonesia.

Email:habibi27021983@yahoo.com,

habibi.2016@student.uny.co.id. 